\title{
Islet neogenesis-associated protein signaling in neonatal pancreatic rat islets: involvement of the cholinergic pathway
}

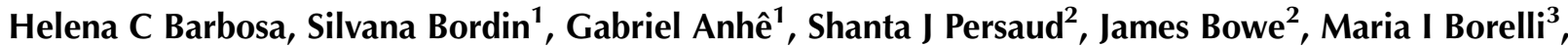 \\ Juan J Gagliardino ${ }^{3}$ and Antonio C Boschero \\ Departamento de Fisiologia e Biofísica, Instituto de Biologia, Universidade Estadual de Campinas, 13083-970 Campinas-SP, São Paulo-SP, Brazil \\ ${ }^{1}$ Departamento de Fisiologia e Biofísica, Instituto de Ciências Biomédicas, Universidade de São Paulo, 05508-900 São Paulo-SP, Brazil \\ ${ }^{2}$ Beta Cell Development and Function Group, Division of Reproduction and Endocrinology, King's College London, SE1 1UL London, UK \\ ${ }^{3}$ CENEXA, Centro de Endocrinología Experimental y Aplicada (UNLP-CONICET, Centro Colaborador de la OPS/OMS), Facultad de Ciencias Médicas, \\ Universidad Nacional de La Plata, 1900 La Plata, Argentina \\ (Correspondence should be addressed to A C Boschero; Email: boschero@unicamp.br)
}

\begin{abstract}
Islet neogenesis associated protein (INGAP) increases islet mass and insulin secretion in neonatal and adult rat islets. In the present study, we measured the short- and long-term effects of INGAP-PP (a pentadecapeptide having the 104118 amino acid sequence of INGAP) upon islet protein expression and phosphorylation of components of the PI3K, MAPK and cholinergic pathways, and on insulin secretion. Short-term exposure of neonatal islets to INGAP-PP $(90 \mathrm{~s}, 5$, 15 , and $30 \mathrm{~min})$ significantly increased $\mathrm{Akt}^{-\mathrm{Ser} 473}$ and MAPK3 $/ 1^{\text {-Thr202/Tyr204 }}$ phosphorylation and INGAP-PP also acutely increased insulin secretion from islets perifused with 2 and $20 \mathrm{mM}$ glucose. Islets cultured for 4 days in the presence of INGAP-PP showed an increased expression of Akt1, Frap1, and Mapk1 mRNAs as well as of the muscarinic M3 receptor subtype, and phospholipase C (PLC)- $\beta 2$ proteins. These islets also showed increased Akt1 and
\end{abstract}

MAPK3/1 protein phosphorylation. Brief exposure of INGAP-PP-treated islets to carbachol (Cch) significantly increased P70S6 $\mathrm{K}^{-\mathrm{Thr} 389}$ and MAPK3/1 phosphorylation and these islets released more insulin when challenged with Cch that was prevented by the M3 receptor antagonist 4-DAMP, in a concentration-dependent manner. In conclusion, these data indicate that short- and long-term exposure to INGAP$\mathrm{PP}$ significantly affects the expression and the phosphorylation of proteins involved in islet PI3K and MAPK signaling pathways. The observations of INGAPP-PP-stimulated up-regulation of cholinergic M3 receptors and PLC- $\beta 2$ proteins, enhanced P70S6K and MAPK3/1 phosphorylation and Cch-induced insulin secretion suggest a participation of the cholinergic pathway in INGAP-PP-mediated effects.

Journal of Endocrinology (2008) 199, 299-306

\section{Introduction}

Islet cell differentiation is controlled by several transcription factors including pancreatic duodenal homeobox-1 (PDX-1), neurogenin3, Nkx-1 and many others (Jensen et al. 2000). Hormonal, chemical, and neural signals are also essential for $\beta$-cell mass adaptation during its intrauterine development (Nielsen et al. 2001). During the fetal and neonatal periods more new $\beta$-cells are formed by neogenesis (Bouwens et al. 1994). Neogenesis is also observed in adult rodents after pancreatic injury such as streptozotocin injection (Fernandes et al. 1997), partial pancreatectomy (Lee et al. 1989), pancreatic duct ligation (Wang et al. 1995, Xu et al. 2008), cellophane wrapping of the pancreas head (Rosenberg \& Vinik 1993), and in sucrose-induced insulin resistance (Del Zotto et al. 1999, 2000, Gagliardino et al. 2003).

Islet neogenesis associated protein (INGAP) was identified as the active part of a pancreatic protein complex isolated from

normal hamsters, whose pancreas heads had been wrapped in cellophane (Pittenger et al. 1992). The Ingap gene is expressed both in normal hamster islets and exocrine cells (Gagliardino et al. 2003) and it has been shown that a pentadecapeptide having the 104-118 amino acid sequence of INGAP (INGAP$\mathrm{PP})$ reproduces the effect of the intact molecule upon thymidine incorporation into ductal cells and a ductal cell line (Rafaeloff et al. 1997). We have reported that offspring from normal hamsters fed a sucrose rich diet during pregnancy have an increase in $\beta$-cell mass, an increased number of PDX-1 and INGAP-positive cells together with the appearance of a small population of cells that co-express PDX-1/INGAP. Since these cells have a high replication rate and do not stain with insulin-, glucagon-, somatostatin-, or PP-antibodies, we postulated that they would be early precursors of islet cells (Gagliardino et al. 2003). Otherwise, it was reported that the administration of the pentadecapeptide to either normal adult mice and dogs or streptozotocin-induced diabetic mice 
induced an increase in $\beta$-cell mass and signs of neogenesis (Rosenberg et al. 2004, Pittenger et al. 2007). In addition, neonatal and adult normal rat islets cultured with INGAP-PP showed both increased $\beta$-cell size and insulin secretion in response to glucose (Borelli et al. 2005).

Since islet transplantation for therapy of type 1 diabetes is hampered by the shortage of islet donors, the search for alternative sources of $\beta$-cells has been intensified. In this sense, endogenous $\beta$-cell mass expansion and, consequently, the reversal of hyperglycemic states in animal models are being actively investigated (Rosenberg et al. 2004, Lipsett et al. 2006). Among the protocols used for this purpose INGAP$\mathrm{PP}$ seems to be a suitable tool, but its mechanism of action is not yet completely elucidated.

It has been reported that the pancreas retains the ability to regenerate a functioning $\beta$-cell mass in the postnatal period (Rosenberg 1995). This process of progenitor cell transformation that leads to islet neogenesis could be mediated, at least in part, by local pancreatic growth factors. It has been shown that INGAP-PP treatment of duct-like structures, obtained from quiescent adult human islets, induced their differentiation to islet-like structures with the four endocrine cell types showing a normal glucose-induced insulin secretion (Jamal et al. 2005). In clinical trials (Ratner et al. 2005a,b) INGAP-PP therapy has been found to reduce daily average blood glucose levels at 90 days in patients with type 2 diabetes and induce a significant increase in C-peptide secretion in patients with type 1 diabetes. Recently, we have further observed that in addition to its effects to stimulate insulin secretion, INGAP-PP treatment augmented the expression of several genes involved in the control of islet growth and development (Barbosa et al. 2006).

Different pathways are involved in the mechanism by which glucose and peptides such as incretin hormones stimulate $\beta$-cell growth and differentiation (Hui et al. 2003, Kluz \& Adamiec 2006). Incretin effects are apparently mediated through stimulation of cyclic AMP/PKA, p42 MAPK and PI3K pathways associated with the transcriptional activity of cyclin D1 (Friedrichsen et al. 2006), while glucose promotes human $\beta$-cell mitogenesis by stimulating $\mathrm{p} 44 / \mathrm{p} 42$ MAPKs and FRAP1/P70S6K phosphorylation (Guillen et al. 2006). These and other reports suggest that MAPK and PI3K cascades may be the major pathways involved in the stimulatory effect of different factors upon islet mass regulation.

In the present study, we show that the enhancing effect of short- and long-term exposure of neonatal rat islets to INGAP-PP upon dynamic insulin secretion is accompanied by an increase of both PI3K and MAPK protein phosphorylation, and of the expression of components of the cholinergic pathway, such as the $\mathrm{M} 3$ receptor subtype and phospholipase C (PLC)- $\beta 2$. Furthermore, Cch significantly increased the short-term induced phosphorylation of proteins from the PI3K and MAPK cascades as well as insulin secretion, suggesting a possible participation of the cholinergic pathway in this process.

\section{Material and Methods}

\section{Reagents}

Reagents used for RT-PCR were from Invitrogen and Sigma. The equipment for SDS-PAGE and immunoblotting was from Bio-Rad. All the chemicals used in the experiments for immunoblotting and buffers were from Sigma. Anti-muscarinic receptor M3 (rabbit polyclonal sc-9108), anti-PLC- $\beta 2$ (rabbit polyclonal, sc-9018), anti-Akt1 (rabbit polyclonal, sc-8312), anti P70S6K (mouse monoclonal sc-8418) anti-phospho $\mathrm{Akt}^{\text {-Ser473 }}$ (rabbit polyclonal, sc-7985), anti-MAPK3 (rabbit polyclonal, sc-94), anti-MAPK 2 (rabbit polyclonal, sc-154), and anti-phospho MAPK3/1-Thr202/Tyr204 (mouse monoclonal sc-7383) antibodies were from Santa Cruz Biotechnology Inc., Santa Cruz, CA, USA; and anti-phospho P70S6K $^{\text {Thr389 }}$ (mouse polyclonal, \#9206S) was from Cell Signaling Technology Inc., Boston, MA, USA.

\section{Islets isolation and culture}

Islets of neonatal Wistar rats were obtained by collagenase digestion of pancreas in Hanks' balanced salt solution and cultured in RPMI-1640 medium supplemented with 5\% fetal bovine serum, $10 \mathrm{mM}$ glucose, $100 \mathrm{IU}$ penicillin $/ \mathrm{ml}, 100 \mu \mathrm{g}$ streptomycin $/ \mathrm{ml}$ at $37^{\circ} \mathrm{C}$ in a $5 \% \mathrm{CO}_{2} /$ air atmosphere. In short-term experiments groups of 300 islets were cultured for two days to minimize contamination by exocrine tissue. In other studies the islets were cultured for 4 days in the absence (controls) or the presence of $10 \mu \mathrm{g} / \mathrm{ml}$ of INGAP-PP, as reported (Barbosa et al. 2006), renewing the medium every day. All animal experiments were approved by the Committee for Ethics in Animal Experimentation of the State University of Campinas (CEEA/IB/UNICAMP).

\section{Insulin secretion}

To study dynamic secretion groups of 60 neonatal rat islets, previously cultured for two days in control conditions, were placed in individual chambers and perifused with krebs ringer buffer (KRB), previously gassed with a mixture of $\mathrm{CO}_{2} / \mathrm{O}_{2}$ $(5 / 95 \%), \mathrm{pH} 7 \cdot 4)$ and maintained at $37^{\circ} \mathrm{C}$ in a temperaturecontrolled environment (Persaud et al. 1989). The islets were first pre-perifused for $1 \mathrm{~h}$ at $2 \mathrm{mM}$ glucose, followed by a 70 min perifusion with the medium containing 2 or $20 \mathrm{mM}$ glucose in the absence or presence of INGAP-PP $(10 \mu \mathrm{g} / \mathrm{ml})$. Medium samples were collected at $2 \mathrm{~min}$ intervals. To study static insulin secretion groups of five neonatal rat islets, previously cultured for 4 days in the absence or presence of INGAP-PP, were then pre-incubated in $0.6 \mathrm{ml}$ of $\mathrm{KRB}$ containing $1.5 \%(\mathrm{w} / \mathrm{v}) \mathrm{BSA}$ and $5.6 \mathrm{mM}$ glucose at $37^{\circ} \mathrm{C}$ for $45 \mathrm{~min}$. After this period, the islets were further incubated in $1 \mathrm{ml} \mathrm{KRB}$ supplemented with $8.3 \mathrm{mM}$ glucose for $1 \mathrm{~h}$ in the absence or presence of $200 \mu \mathrm{M}$ Cch and 1-100 nM 4-DAMP (Boschero et al. 1995). Aliquots from the static incubation and perifusion experiments were stored frozen for insulin 
measurement by RIA. Islets from all experiments were lysed in alcohol-acid solution for insulin extraction and subsequent insulin immunoassay (data not shown). All results were normalized against insulin content from each well or chamber.

\section{RT-PCR}

Semi-quantitative RT-PCR was performed using specific primers to analyze gene expression of Akt1 (NM 033230), FRAP1 (NM 019906), and MAPK1 (M 64300). Reverse transcription was carried out with $3 \mu \mathrm{g}$ total RNA using Moloney murine leukemia virus reverse transcriptase (Superscript II) and random hexamers, according to the manufacturer's instructions (Invitrogen). RT-PCR assays were done in quadruplicate using recombinant Taq DNA polymerase (Invitrogen) and $10 \mathrm{pM}$ of each primer in a master mix of $50 \mu \mathrm{l}$. The primer sets used in the RT-PCR analyses are shown in Table 1. The number of cycles for each gene was defined after titration using 20 to 42 cycles and was within the logarithmic phase of amplification. PCR products were separated on $1.5 \%$ $\mathrm{EtBr}$-agarose gels and the band intensities were determined by digital scanning (GelDoc 2000, Bio-Rad) followed by quantification using Scion Image analysis software (Scion Corp., Frederick, MD, USA). The results were expressed as a ratio of target to ribosomal protein (RP)S-29 signals. The RNAs used for RT-PCR analysis were obtained from three sets of experiments.

\section{Tissue extracts and immunoblotting}

Cultured islets were homogenized in $100 \mu$ l solubilizing buffer

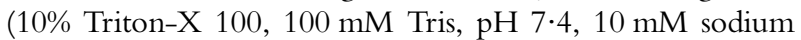
pyrophosphate, $100 \mathrm{mM}$ sodium fluoride, $10 \mathrm{mM}$ EDTA, $10 \mathrm{mM}$ sodium vanadate, and $2 \mathrm{mM}$ phenylmethylsulphonyl fluoride) for $30 \mathrm{~s}$ using a Polytron PT $1200 \mathrm{C}$ homogenizer (Brinkmann Instruments, Westbury, NY, USA) and boiled for $5 \mathrm{~min}$. The extracts were then centrifuged at $12600 \mathrm{~g}$ at $4{ }^{\circ} \mathrm{C}$ for $20 \mathrm{~min}$ to remove insoluble material. The protein concentration in the supernatants was assayed using the Bradford dye method and the BioR ad reagent. The proteins obtained were treated with Laemmli sample buffer containing dithiothreitol and boiled for $5 \mathrm{~min}$. Seventy micrograms of protein from each sample were then applied to a $10 \%$ polyacrylamide gel and separated by SDS-PAGE in a BioRad miniature slab gel apparatus. The protein fractions were thereafter electrotransfered from the gel to nitrocellulose at $120 \mathrm{~V}$ for $90 \mathrm{~min}$ in a BioRad miniature transfer apparatus. Before incubation with the primary antibody, the nitrocellulose filters were treated with a blocking buffer (5\% non-fat dried milk, $10 \mathrm{mM}$ Trizma, $150 \mathrm{mM} \mathrm{NaCl}$, and $0.02 \%$ Tween 20 ) for $2 \mathrm{~h}$ at $22^{\circ} \mathrm{C}$. The membranes were then incubated for $4 \mathrm{~h}$ at $22^{\circ} \mathrm{C}$ with antibodies against muscarinic receptor M3 (1:500), PLC- $\beta 2$ (1:1,000), p-MAPK3/1 (1:500), MAPK3/1 (1:1,000), P70S6K (1:500), p-P70S6K (1:1,000), Akt1 (1:500) or p-Akt1 (1:500) diluted in blocking buffer with 3\% non-fat dried milk, and then washed for $30 \mathrm{~min}$ in blocking buffer without milk. The blots were subsequently incubated with peroxidase-conjugated second antibody for $1 \mathrm{~h}$. Specific protein bands were revealed using commercial enhanced chemiluminescence reagents with exposure to photographic film. The images were obtained by digital scanning on GelDoc 2000, BioRad, followed by quantification using Scion Image analysis software (Scion Corp).

\section{Statistical analysis}

Results are shown as means \pm s.E.M.; appropriate statistical comparisons between INGAP-PP-treated islets and the respective control groups were carried out using Student's unpaired $t$-test. Differences were considered significant when $P$ values were $<0 \cdot 05$.

\section{Results}

Short-term effect of INGAP-PP on islet Akt 1 and MAPK3/1 phosphorylation and on insulin secretion

Akt1 phosphorylation increased twofold when neonatal rat islets were exposed to $10 \mu \mathrm{g} / \mathrm{ml}$ INGAP-PP for either $90 \mathrm{~s}$ or $5 \mathrm{~min}(P<0 \cdot 05)$, returning to control values after $15 \mathrm{~min}$ (Fig. 1A). INGAP-PP also significantly increased MAPK3/ $1^{\text {-Thr202/Tyr204 }}$ phosphorylation that lasted for $30 \mathrm{~min}$ after the peptide exposure, being $4 \cdot 1-, 4 \cdot 0-, 2 \cdot 2-$, and $2 \cdot 8$-fold higher than control at $90 \mathrm{~s}, 5,15$, and $30 \mathrm{~min}$ respectively $(P<0 \cdot 05$; Fig. 1B). To verify whether insulin secretion was also affected by exposure to INGAP-PP, islets were perifused with a buffer medium containing $2 \mathrm{mM}$ or $20 \mathrm{mM}$ glucose in the absence or presence of the peptide $(10 \mu \mathrm{g} / \mathrm{ml})$. At $2 \mathrm{mM}$ glucose (Fig. 2A) addition of INGAP-PP provoked a rapid and sustained twofold increase in insulin secretion ( $\min 11-30$ ). This effect was rapidly reversed by the removal of INGAP-PP from the perifusion medium. To determine whether the islets maintained their viability after INGAP-PP exposure, the glucose concentration was increased to $20 \mathrm{mM}$ (min 51-70) and this resulted in a significant increase in the insulin

Table 1 RT-PCR primer sets with predicted product sizes

\begin{tabular}{|c|c|c|c|c|c|c|}
\hline & Genebank & Forward primer & Reverse primer & $\operatorname{TM}\left({ }^{\circ} \mathrm{C}\right)$ & Cycle number & Product $(b p)$ \\
\hline \multicolumn{7}{|l|}{ Gene } \\
\hline Akt1 & NM 033230 & ССТСААGTAСТСАТTССАGАС & СТCATACACATCTTGCСАCAC & 58 & 26 & 619 \\
\hline Frap1 & NM 019906 & AAGGAGATGCAGAAGCCTCAGT & TGTCCCAAAGCCCATTAGGTCT & 58 & 29 & 249 \\
\hline Mapk1 & M 64300 & GACCCAAGTGATGAGCCCATTG & AAGCCACTACGACCAGACTGCC & 56 & 24 & 253 \\
\hline
\end{tabular}




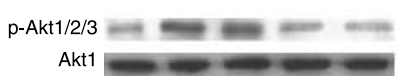

A

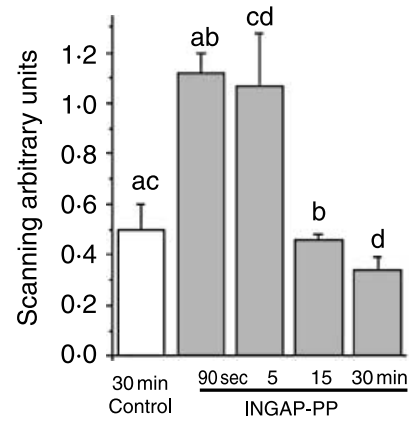

MAPK3/1

$\mathrm{MAPK} 3 / 1$

\section{$\mathrm{B}$}

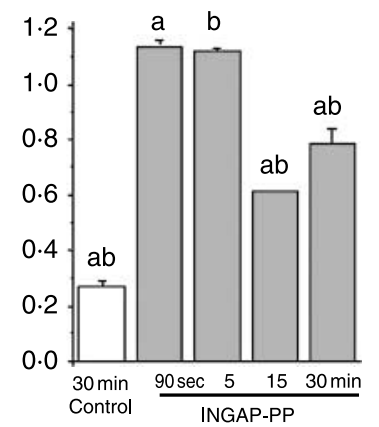

Figure 1 Acute effects of INGAP-PP on Akt1 and MAPK3/1 phosphorylation in neonatal rat islets. Two days cultured control islets were acutely exposed to $10 \mu \mathrm{g} / \mathrm{ml}$ of INGAP-PP for $90 \mathrm{~s}, 5,15$, and $30 \mathrm{~min}$ and islet extracts were immunoblotted with antiphospho-Akt1 (A) and anti-phospho- MAPK3/1 (B) antibodies. The bars represent the relative phosphorylation of the proteins (normalized against the total protein) measured by optical densitometry, and are the means \pm S.E.M. of four experiments. The same letters indicate the pair comparisons that are significantly different $(P<0 \cdot 05)$.

secretion. Figure $2 \mathrm{~B}$ shows that increasing the glucose concentration from 2 to $20 \mathrm{mM}$ (min 11-30) stimulated insulin secretion from perifused islets and that this secretory response was further potentiated by INGAP-PP (min 31-50) to levels approximately twofold higher than those obtained with $20 \mathrm{mM}$ glucose alone. However, the potentiation of insulin secretion induced by INGAP-PP was transient and insulin levels returned to values comparable with those elicited by $20 \mathrm{mM}$ glucose before INGAP-PP withdrawal.

\section{Long-term effect of INGAP-PP on islet Akt1, Frap 1 and Mapk1 gene expression, and Akt1 and Mapk3/1 phosphorylation}

RNA obtained from islets that had been maintained in the presence of INGAP-PP for 4 days was submitted to semiquantitative RT-PCR analysis and normalized against the RPS29 housekeeping gene. INGAP-PP induced in cultured islets a significant increase in Akt1, Frap1 and Mapk1 gene expression attaining 1·9-, 1·6-, and 1·5-fold higher values than control islets $(\mathrm{P}<0 \cdot 05$; Fig. 3A). Islets that had been exposed to INGAP-PP for 4 days also showed increased basal phosphorylation of Akt 1 and MAPK3/1, with levels $1 \cdot 8$ - and $1 \cdot 5$ - fold respectively higher than control islets $(P<0 \cdot 05$; Fig. $3 \mathrm{~B})$.

Long-term effect of INGAP-PP on the expression of muscarinic $M 3$ subtype receptor, PLC- $\beta 2$ proteins, and on $C$ ch-induced acute phosphorylation of P70S6K and MAPK3/1

Due to the role of cholinergic pathway in the mechanism of insulin secretion, induced either by acetylcholine or glucose,
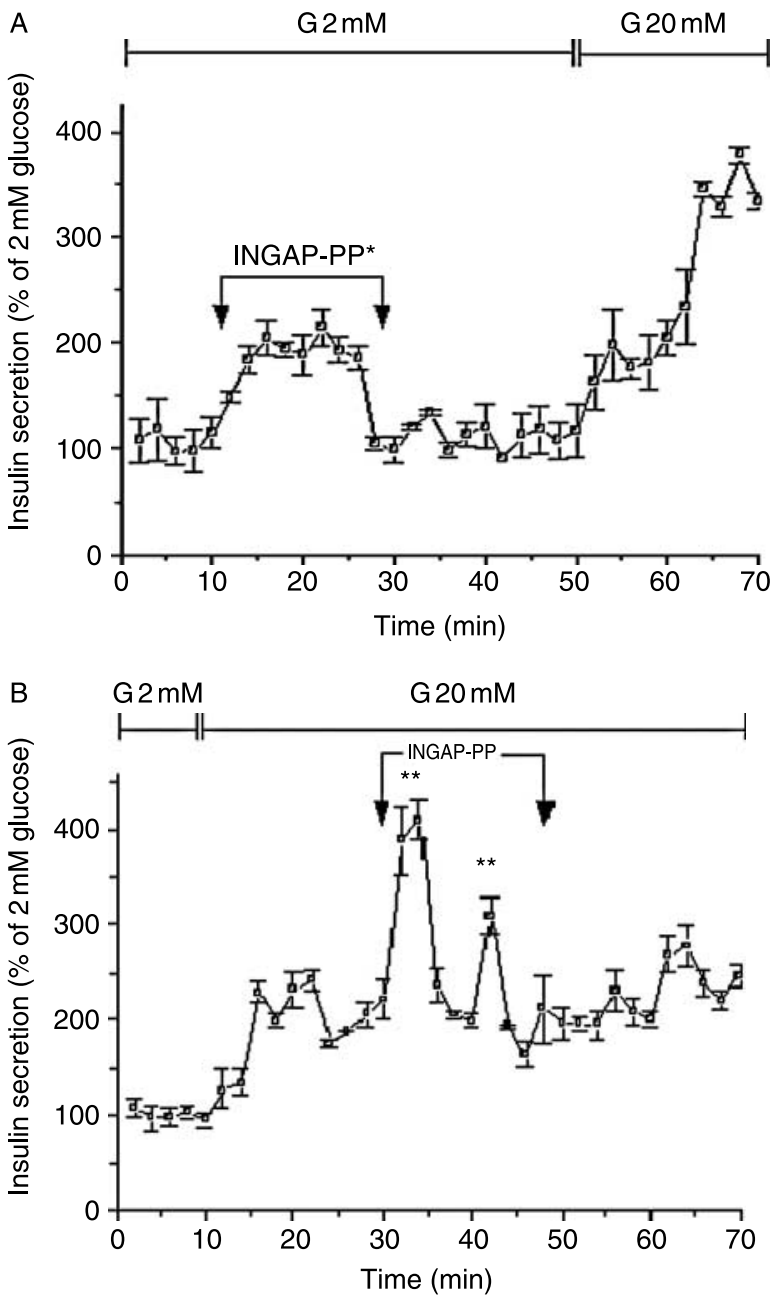

Figure 2 Kinetics of INGAP-PP-evoked stimulation of insulin secretion. Two-day cultured control islets were continuously perifused with $\mathrm{KRB}$ buffer at $37^{\circ} \mathrm{C}$. After a pre-incubation period of $1 \mathrm{~h}$ (2 mM glucose) the effluent was collected each $2 \mathrm{~min}$ for $70 \mathrm{~min}$. INGAP-PP $(10 \mu \mathrm{g} / \mathrm{ml})$ was applied as indicated either in the presence of $2 \mathrm{mM}$ (A) or $20 \mathrm{mM}$ glucose (B). Results are expressed as \% of mean values calculated for min 0-10 (2 mM glucose), and normalized against total insulin content. Insulin secretion rates are means \pm S.E.M. from three different experiments, $* P<0 \cdot 05$ compared with basal insulin secretion ( $2 \mathrm{mM}$ glucose) and ** $P<0.05$ compared with $20 \mathrm{mM}$ glucose.

and considering that gene expression of the M3 receptor subtype was up-regulated by INGAP-PP after 4 days culture, in the next series of experiments we analyzed $\mathrm{M} 3$ receptor and PLC- $\beta 2$ expression as well as the effect of Cch on protein phosphorylation of the PI3K and MAPK pathways. Protein levels of the muscarinic M3 receptor subtype and PLC- $\beta 2$ were significantly higher in islets cultured for 4 days in the presence of INGAP-PP than in controls (Fig. 4A and B). Basal P70S6K phosphorylation was similar in INGAPPP-treated and control islets and exposure of these islets to $200 \mu \mathrm{M}$ Cch for short periods of time (90 s, 5 and $15 \mathrm{~min}$ ) 

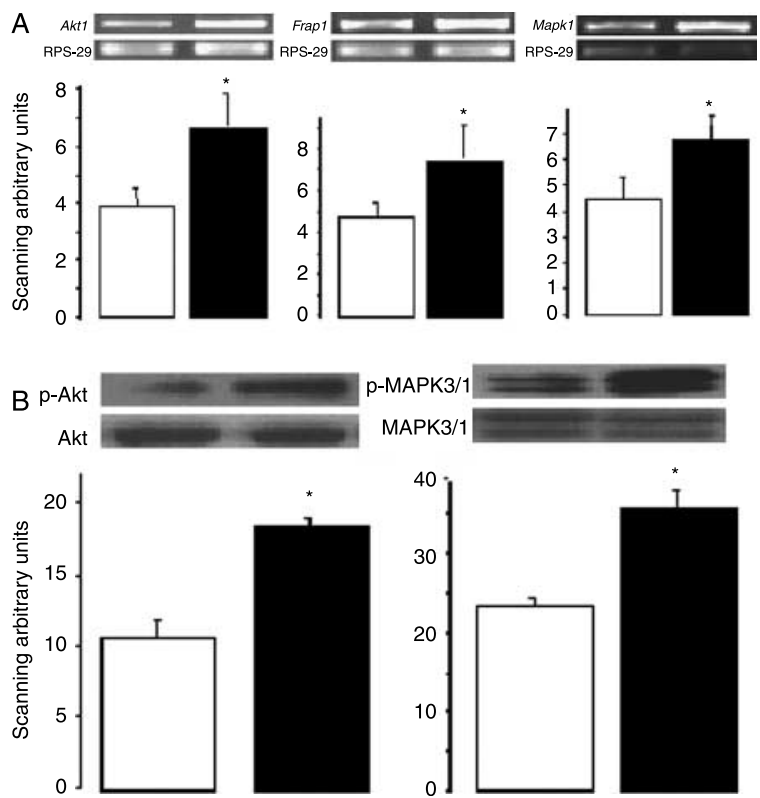

*
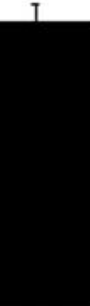

Figure 3 Effects of culture with $10 \mu \mathrm{g} / \mathrm{ml}$ of INGAP-PP for 4 days on mRNA levels of Akt1, Frap1, and Mapk1 (A), and on Akt1 and Mapk3/1 (B) phosphorylation. A: RT-PCRs annealing temperatures and cycle numbers used were as follows: $58{ }^{\circ} \mathrm{C}$ and 26 cycles for Akt $1 ; 58{ }^{\circ} \mathrm{C}$ and 29 cycles for Frap $1 ; 56^{\circ} \mathrm{C}$ and 24 cycles for MAPK1. Results were normalized to the RPS-29 housekeeping gene. $\mathrm{B}$ : islet extracts were immunoblotted with anti-phospho-Akt1 and anti-phospho-MAPK3/1 antibodies (normalized against the total protein). Plotted columns are means \pm s.E.M. of 12 experiments for mRNA and four experiments for protein phosphorylation.

$* P<0 \cdot 05$ versus control.

significantly increased phosphorylation in both groups. However, Cch-stimulated P70 S6K phosphorylation was significantly higher in INGAP-PP-treated islets than in control islets $(4 \cdot 4-, 6 \cdot 9$ - and $4 \cdot 3$-fold for INGAP-PP-treated versus $2 \cdot 5-, 1 \cdot 5$ - and $2 \cdot 0$-fold for control islets at $90 \mathrm{~s}, 5$, and 15 min respectively; $P<0 \cdot 05$; Fig. 5 A). MAPK3/1 phosphorylation was also similar in INGAP-PP-treated and control islets and exposure to Cch for $90 \mathrm{~s}$ induced a similar and significant increase in MAPK3/1 phosphorylation in treated and control islets $(3 \cdot 2$-fold $)$ compared with appropriate controls (no Cch). While the Cch-induced MAPK3/1 phosphorylation increment returned to basal values after $5 \mathrm{~min}$ in control islets, it remained significantly higher in INGAP-PP-cultured islets at 5 and $15 \mathrm{~min}(3.7$ and $2 \cdot 3$ versus control respectively; $\mathrm{P}<0 \cdot 05$; Fig. $5 \mathrm{~B}$ ).

Effects of Cch on insulin release from INGAP-PP-cultured and control islets

Insulin secretion at $8.3 \mathrm{mM}$ glucose was higher in INGAPPP-cultured islets compared with control islets $(P<0 \cdot 05$; Fig. 6). When $200 \mu \mathrm{M}$ Cch was added to the incubation medium insulin secretion increased $5 \cdot 7$ times in the INGAPPP-cultured and 1.5 times in the control islets. This

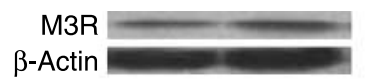

\section{PLC- $\beta 2$ $\beta$-Actin}
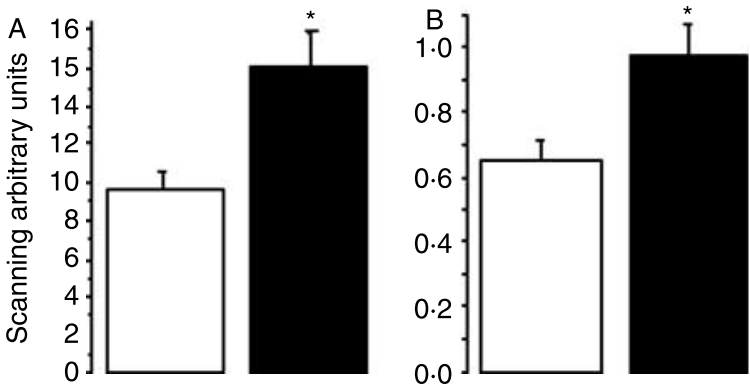

Figure 4 Effect of culture with $10 \mu \mathrm{g} / \mathrm{ml}$ of INGAP-PP for 4 days on muscarinic receptor M3 subtype (A) and PLC- $\beta 2$ (B) expression. Islet extracts were immunoblotted with anti-muscarinic receptor and anti-PLC- $\beta 2$ antibodies. The bars represent the relative protein expression as determined by optical densitometry, and are the means \pm S.E.M. of three experiments, normalized to $\beta$-actin protein expression, * $P<0.05$ versus controls. Open and closed bars represent islets from control and INGAP-PP-cultured rat islets, respectively.

stimulatory effect of Cch was dose-dependently inhibited by increasing concentrations of 4-diphenylacetoxy-N-methylpiperidine (DAMP), a selective antagonist of M3 receptors, with complete inhibition observed at $10 \mathrm{nM}$ for INGAP$\mathrm{PP}$-cultured islets and at $1 \mathrm{nM}$ for control islets.

\section{Discussion}

It is generally accepted INGAP-PP increases $\beta$-cell mass and insulin secretion in response to different stimuli (Borelli et al. 2005, Jamal et al. 2005, Barbosa et al. 2006, Lipsett et al. 2006). We have also recently demonstrated that INGAP-PP simultaneously enhanced insulin secretion and up-regulated several genes related to protein synthesis and islet maturation in neonatal rat islets (Barbosa et al. 2006). However, the mechanism by which INGAP-PP produced these effects is not yet fully elucidated. It has been reported that culturing isolated adult human islets for 10 days in a simple medium resulted in the disappearance of $\beta$-cells from the islet core and when these ghost islets were cultured with INGAP-PP for 4 days the islets were rebuilt and the newly formed $\beta$-cells released insulin in response to glucose at levels comparable with freshly isolated adult islets. Using a variety of blockers it was concluded that the effects of INGAP-PP were due to activation of the PI3K pathway (Jamal et al. 2005). It is still a matter of debate whether most of the new $\beta$-cells in adult animals are formed by the replication of resident $\beta$-cells (Dor et al. 2004) or if they are derived from ductal or other pancreatic precursor cells (Noguchi et al. 2006, Yatoh et al. 2007, Xu et al. 2008). Jamal et al. (2005) have suggested that the enhancing effect of INGAP-PP upon $\beta$-cell mass was obtained by a direct effect upon the remaining external islet cells that presumably conserves characteristics of ductal cells. 


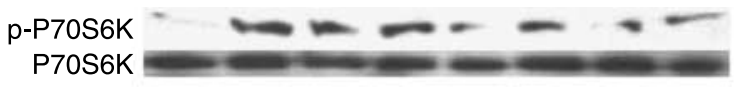

A INGAP-PP-cultured
islets
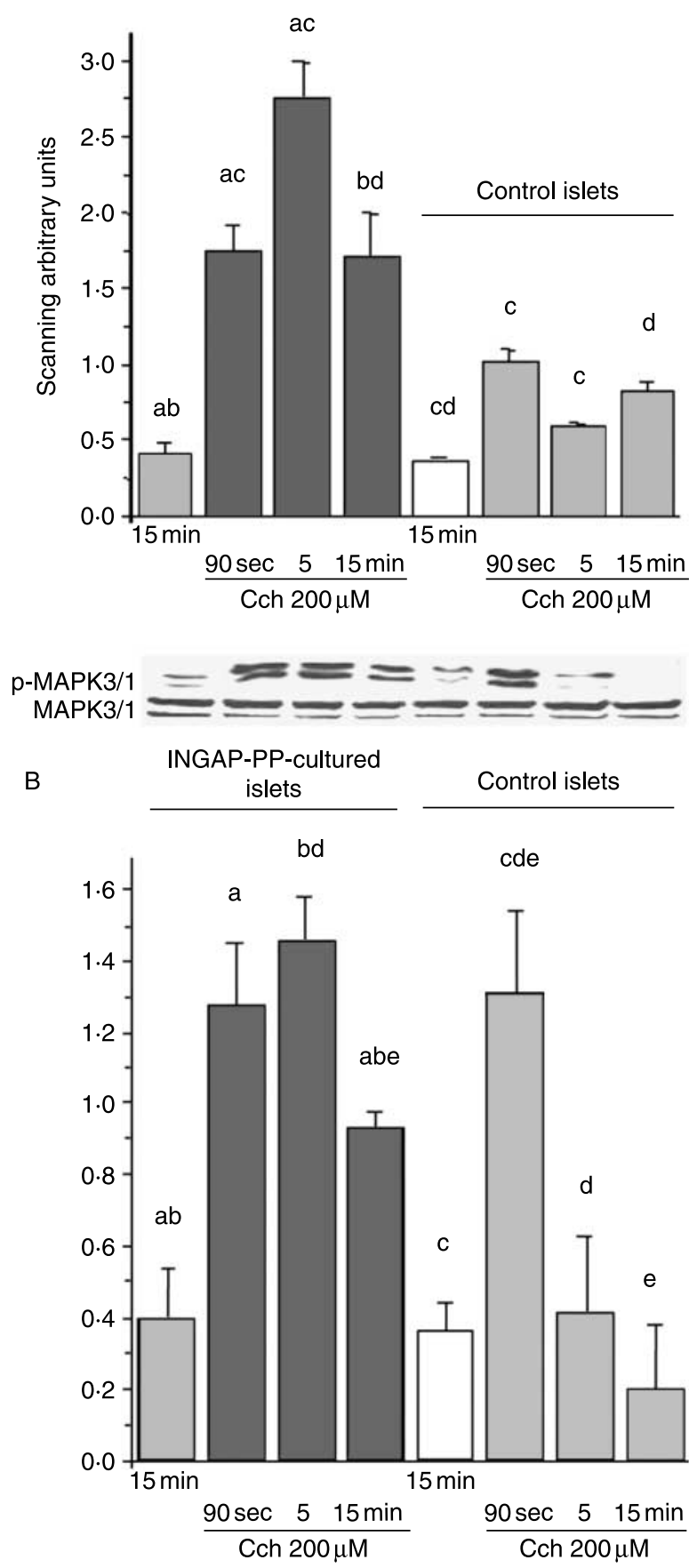

Neonatal islets exposed to INGAP-PP for short periods of time ( $90 \mathrm{~s}, 5,15$, and $30 \mathrm{~min}$ ) showed a significant increase in Akt1/2/3- and MAPK3/1 phosphorylation (Fig. 1) supporting the early proposal that both PI3K and MAPK pathways may act as intracellular mediators of the beneficial effect of INGAP-PP upon $\beta$-cell mass and viability (Jamal et al. 2005). These short-term effects of INGAP-PP upon the phosphorylation of proteins that belong to the PI3K and MAPK cascades were also observed when neonatal islets were cultured with INGAP-PP for 4 days (Akt1 and MAPK3/1) together with an increase of Akt1, Frap1, and Mapk1 gene expression.

Long-term exposure of neonatal islets to INGAP-PP also increased expression of members of the cholinergic pathway, namely the M3 receptor subtype and PLC- $\beta 2$. Furthermore, 4-DAMP (a selective M3 inhibitor) significantly inhibited Cchstimulated insulin release. These results strongly suggest that the enhanced insulin secretion induced by cholinergic stimulus in INGAP-PP-cultured islets was due, at least in part, to an increase in the expression of the M3 muscarinic receptor subtype. It has been reported that in MIN6 $\beta$-cells, PLC activation by $\mathrm{Ca}^{2+}$ is an essential step for the stimulatory effect of Cch upon insulin secretion (Thore et al. 2005); such a mechanism includes an intracellular $\mathrm{Ca}^{2+}$ mobilization phase and a sustained activation phase dependent on $\mathrm{Ca}^{2+}$ entry through non voltagedependent channels present in the plasma membrane. Since the expression of PLC $\beta 2$ was increased in INGAP-PP-cultured islets it is conceivable that higher levels of intracellular $\left[\mathrm{Ca}^{2+}\right]$ in these islets (Silva et al. 2008) could account for the increased secretion of insulin via a higher PLC- $\beta 2$ activity. The increased expression of the two $\mathrm{K}_{-\mathrm{ATP}}^{+}$dependent channels component genes (Barbosa et al. 2006) and the increase in intracellular $\left[\mathrm{Ca}^{2+}\right]$, would also contribute to the enhanced release of insulin observed in INGAP-PP cultured islets. Furthermore, Cch significantly augmented P70S6K and MAPK3/1 protein phosphorylation in these islets. Altogether, these results suggest participation of the cholinergic pathway in the mechanism by which INGAP-PP increases insulin secretion.

Activation of PI3K and MAPK pathway proteins occurs following both short- and long-term exposure to INGAP-PP. It has been shown that activation of those pathways is a common mechanism shared by several hormones, growth factors and substances that affect tissue growth and differentiation in many cell types. For example, MAPK3/1 phosphorylation is potentiated by glucose, incretins, IGF-1 and glyburide in INS-1 cells (Briaud et al. 2003). Prolactin also activates PI3K and

Figure 5 Acute effects of $200 \mu \mathrm{M}$ Cch on P70S6K and MAPK3/1 phosphorylation in islets for 4 days in the absence or presence of $10 \mu \mathrm{g} / \mathrm{ml}$ INGAP-PP. After culture, control and INGAP-PP islets were exposed to Cch for $90 \mathrm{~s}, 5$, and $15 \mathrm{~min}$. Islet extracts were immunoblotted with anti-phospho-P70S6K (A) and anti-phosphoMAPK3/1 (B) antibodies. The bars represent the relative phosphorylation of the proteins (normalized against the total protein) determined by optical densitometry, and are the means \pm s.E.M. of four experiments. The same letters indicate the pairs comparisons that are significantly different $(P<0 \cdot 05)$. 


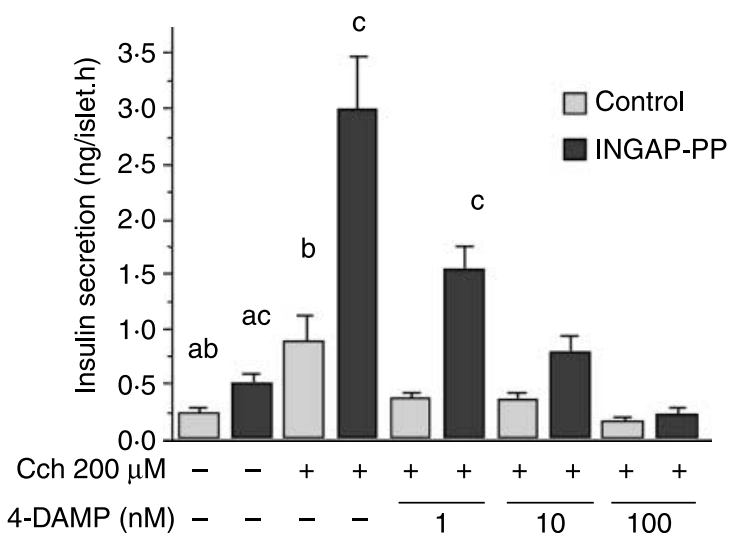

Figure 6 Effect of 4-DAMP on $200 \mu \mathrm{M}$ Cch-induced insulin secretion in control and INGAP-PP-cultured $(10 \mu \mathrm{g} / \mathrm{ml})$ neonatal rat islets for 4 days. After culture, groups of 5 islets were incubated in KRB buffer containing $8.3 \mathrm{mM}$ glucose in the absence or presence of $200 \mu \mathrm{M}$ Cch and increasing concentrations of the M3 receptor antagonist 4-DAMP (1 $\mathrm{nM}, 10 \mathrm{nM}$ and $100 \mathrm{nM})$. The bars represent cumulative $1 \mathrm{~h}$ insulin secretion and are means \pm S.E.M. of 14-20 groups of islets from three different experiments. The same letters indicate the pairs comparisons that are significantly different $(P<0 \cdot 05)$ between groups. Light and dark bars represent islets from control and INGAP-PP-cultured islets respectively.

MAPK cascades in cultured neonatal rat islets and in islets from pregnant rats, underlining the importance of these pathways in growth and development of islets in both periods of life (Amaral et al. 2003, 2004). In addition, MAPK6, a member of the MAPK cascade, is involved in the process of insulin granule exocytosis possibly through the complex MAPK6/MAP2, and via conventional PKCs activation (Anhe et al. 2006, Cunha et al. 2007). Moreover, it has been postulated that phosphorylation of synapsin I, a protein involved in glucose-induced insulin secretion, is dependent on MAPK3/1 activation (Longuet et al. 2005). Thus, our findings concerning INGAP-PP-induced phosphorylation of proteins of the MAPK and PI3K pathways are in good agreement with the literature mentioned above.

There is also evidence of participation of the cholinergic pathway in cell growth in other tissues. Thus, a) Cch increases $\left[\mathrm{Ca}^{2+}\right] \mathrm{i}$, MAPK1 phosphorylation, protein synthesis, and cell proliferation in a human breast cancer cell line (Jimenez \& Montiel 2005); b) M3 muscarinic cholinergic receptors activate p70S6K1 via PI3K signaling pathway in astrocytoma cells (Tang et al. 2003, Batty et al. 2004); c) a novel pathway of acetylcholine-stimulated activation of eNOS, involving the JAK2/IRS-1/PI3K/ Akt1 pathway, has recently been reported in aorta of obese rats that are simultaneously resistant to insulin and Cch (Zecchin et al. 2007); and d) islet M1 and M3 muscarinic receptor expression is increased during islet cell regeneration (Renuka et al. 2005). The increased expression of such receptors is associated with an increase in insulin secretion that, in turn, might modulate $\beta$-cell growth and differentiation via IRS2 activation (Velloso et al. 1995).
In conclusion, our data show that both short- and longterm exposure of neonatal normal rat islets to INGAP-PP activates islet PI3K and MAPK pathways and increases the expression of muscarinic M3 receptors and PLC- $\beta 2$ proteins. In INGAP-PP-cultured islets, a brief exposure to Cch enhanced the phosphorylation of several components of both signaling cascades leading to an increase in insulin secretion. This latter phenomenon suggests that the effect of INGAP-PP upon pancreatic islets is due, at least in part, to the activation of the cholinergic pathway. In light of the beneficial effects of INGAP-PP on $\beta$-cell function INGAP-PP supplementation of human islets, maintained in culture prior to transplantation therapy, could be a suitable strategy to optimize their viability and secretory function.

\section{Declaration of interest}

The authors declare that there is no conflict of interest that could be perceived as prejudicing the impartiality of the research reported.

\section{Funding}

This work was partially supported by the Brazilian foundations: CAPES, CNPQ, FAPESP, and by the UK Society for Endocrinology Small Grant Programme.

\section{Acknowledgements}

We are grateful to Lécio D Teixeira for the technical.

\section{References}

Amaral MEC, Ueno M, Carvalheira JB, Carneiro EM, Velloso LA, Saad MJA \& Boschero AC 2003 Prolactin signal transduction in neonatal rat pancreatic islets and interaction with insulin signaling pathway. Hormone and Metabolic Research 35 282-289.

Amaral MEC, Cunha DA, Anhê GF, Ueno M, Carneiro EM, Velloso LA, Bordin S \& Boschero AC 2004 Participation of prolactin receptors and PI3K and MAPK pathways in the increase in pancreatic islet mass and sensitivity to glucose during pregnancy. Journal of Endocrinology 183 469-476.

Anhe GF, Torrao AS, Nogueira TC, Caperuto LC, Amaral ME, Medina MC, Azevedo-Martins AK, Carpinelli AR, Carvalho CR, Curi R et al. 2006 ERK3 associates with MAP2 and is involved in glucose-induced insulin secretion. Molecular and Cellular Endocrinology 251 33-41.

Barbosa HC, Bordin S, Stoppiglia L, Silva K, Borelli M, Del Zotto H, Gagliardino J \& Boschero A 2006 Islet neogenesis associated protein (INGAP) modulates gene expression in cultured neonatal rat islets. Regulatory Peptides 136 78-84.

Batty IH, Fleming IN \& Downes CP 2004 Muscarinic-receptor-mediated inhibition of insulin-like growth factor-1 receptor-stimulated phosphoinositide 3-kinase signalling in $1321 \mathrm{~N} 1$ astrocytoma cells. Biochemical Journal 379 641-651.

Borelli MI, Stoppiglia LF, Rezende LF, Flores LE, Del Zotto H, Boschero AC \& Gagliardino JJ 2005 INGAP-related pentadecapeptide: its modulatory effect upon insulin secretion. Regulatory Peptides 131 97-102.

Boschero AC, Szpak-Glasman M, Carneiro EM, Bordin S, Paul I, Rojas E \& Atwater E 1995 Oxotremorine-m potentiation of glucose-induced insulin release from rat islets involves M3 muscarinic receptors. American Journal of Physiology 268 E336-E342. 
Bouwens L, Wang RN, de Blay E, Pipeleers DG \& Klöppel G 1994 Cytokeratins as markers of ductal cell differentiation and islet neogenesis in the neonatal rat pancreas. Diabetes 43 1279-1283.

Briaud I, Lingohr MK, Dickson LM, Wrede CE \& Rhodes CJ 2003 Differential activation mechanisms of Erk-1/2 and p70(S6K) by glucose in pancreatic beta-cells. Diabetes 52 974-983.

Cunha DA, Roma LP \& Boschero AC 2007 Prolactin modulates the association and phosphorylation of SNARE and kinesin/MAP-2 proteins in neonatal pancreatic rat islets. Molecular and Cellular Endocrinology 273 32-41.

Del Zotto H, Massa L, Gómez Dumm CL \& Gagliardino JJ 1999 Changes induced by sucrose administration upon the morphology and function of pancreatic islets in the normal hamster. Diabetes/Metabolism Research and Reviews 15 106-112.

Del Zotto H, Massa L, Rafaeloff R, Pittenger GL, Vinik A, Gold G, ReifelMiller A \& Gagliardino JJ 2000 Possible relationship between changes in islet neogenesis and islet neogenesis-associated protein-positive cell mass induced by sucrose administration to normal hamsters. Journal of Endocrinology 165 725-733.

Dor Y, Brown J, Martinez OI \& Melton DA 2004 Adult pancreatic beta-cells are formed by self-duplication rather than stem-cell differentiation. Nature 429 41-46.

Fernandes A, King LC, Guz Y, Stein R, Wright CV \& Teitelman G 1997 Differentiation of new insulin-producing cells is induced by injury in adult pancreatic islets. Endocrinology 138 1750-1762.

Friedrichsen BN, Neubauer N, Lee YC, Gram VK, Blume N, Petersen JS, Nielsen JH \& Moldrup A 2006 Stimulation of pancreatic beta-cell replication by incretins involves transcriptional induction of cyclin D1 via multiple signaling pathways. Journal of Endocrinology 188 481-492.

Gagliardino JJ, Del Zotto H, Massa L, Flores LE \& Borelli M 2003 Pancreatic duodenal homeobox-1 and islet neogenesis-associated protein: a possible combined marker of activateable pancreatic cell precursors. Journal of Endocrinology 177 249-259.

Guillen C, Navarro P, Robledo M, Valverde AM \& Benito M 2006 Differential mitogenic signaling in insulin receptor-deficient fetal pancreatic beta-cells. Endocrinology 147 1959-1968.

Hui H, Nourparvar A, Zhao X \& Perfetti R 2003 Glucagon-like peptide-1 inhibits apoptosis of insulin-secreting cells via a cyclic $5^{\prime}$-adenosine monophosphate-dependent protein kinase A- and a phosphatidylinositol 3-kinase-dependent pathway. Endocrinology 144 1444-1455.

Jamal AM, Lipsett M, Sladek R, Laganiére S, Hanley S \& Rosenberg L 2005 Morphogenetic plasticity of adult human pancreatic islets of Langerhans. Cell Death and Differentiation 12 702-712.

Jensen J, Heller RS, Funder-Nielsen T, Pedersen EE, Lindsell C, Weinmaster G, Madsen OD \& Serup P 2000 Independent development of pancreatic alphaand beta-cells from neurogenin3-expressing precursors: a role for the notch pathway in repression of premature differentiation. Diabetes 49 163-176.

Jimenez E \& Montiel M 2005 Activation of MAP kinase by muscarinic cholinergic receptors induces cell proliferation and protein synthesis in human breast cancer cells. Journal of Cellular Physiology 204 678-686.

Kluz J \& Adamiec R 2006 New therapeutic approach in patients with type 2 diabetes based on glucagon-like peptide 1 (GLP-1) and gastric inhibitory peptide (GIP). Postepy Higieny i Medycyny Doświadczalnej 60 15-23.

Lee HC, Bonner-Weir S, Weir GC \& Leahy JL 1989 Compensatory adaptation to partial pancreatectomy in the rat. Endocrinology 124 1571-1575.

Lipsett MA, Austin EB, Castellarin ML, Lemay J \& Rosenberg L 2006 Evidence for the homeostatic regulation of induced beta cell mass expansion. Diabetologia 49 2910-2919.

Longuet C, Broca C, Costes S, Hani EH, Bataille D \& Dalle S 2005 Extracellular regulated kinases 1/2 (p44/42 mitogen-activated protein kinase) phosphorylate synapsin I and regulate insulin secretion in the MIN6 beta-cells line and islets of Langerhans. Endocrinology 146 643-654.

Nielsen JH, Galsgaard ED, Møldrup A, Friedrichsen BN, Billestrup N, Hansen JA, Lee YC \& Carlsson C 2001 Regulation of $\beta$-cell mass by hormones and growth factors. Diabetes 50 S25-S29.

Noguchi H, Xu G, Matsumoto S, Kaneto H, Kobayashi N, Bonner-Weir S \& Hayashi S 2006 Induction of pancreatic stem/progenitor cells into insulinproducing cells by adenoviral-mediated gene transfer technology. Cell Transplantation 15 929-938.
Persaud SJ, Jones PM, Sugden D \& Howell SL 1989 The role of protein kinase $\mathrm{C}$ in cholinergic stimulation of insulin secretion from rat islets of Langerhans. Biochemical Journal 264 753-758.

Pittenger GL, Rosenberg LG \& Vinik A 1992 The partial isolation and characterization of ilotropin, a novel islet-specific growth factor. Advances in Experimental Medicine and Biology 321 123-130.

Pittenger GL, Taylor-Fishwick DA, Johns RH, Burcus N, Kosuri S \& Vinik AI 2007 Intramuscular injection of islet neogenesis-associated protein peptide stimulates pancreatic islet neogenesis in healthy dogs. Pancreas $\mathbf{3 4}$ 103-111.

Rafaeloff R, Pittenger GL, Barlow SW, Qin XF, Yan B, Rosenberg L, Duguid WP \& Vinik AI 1997 Cloning and sequencing of the pancreatic islet neogenesis associated protein (INGAP) gene and its expression in islet neogenesis in hamsters. Journal of Clinical Investigation 99 2100-2109.

Ratner RE, Feeley D, Buse JB \& Fisher JS 2005a Double-blind, placebocontrolled trial of islet neogenesis gene associated protein (INGAP) therapy in type 2 diabetes (T2DM) subjects. Proceedings of American Diabetes Association Society 12-LB (Abstract).

Ratner RE, Feeley D, Buse JB \& Schwartz SL 2005b Double-blind, placebocontrolled trial of islet neogenesis gene associated protein (INGAP) therapy in type 1 diabetes (T1DM) subjects. Proceedings of American Diabetes Association Society 11-LB (Abstract).

Renuka TR, Savitha B \& Paulose CS 2005 Muscarinic M1 and M3 receptor binding alterations in pancreas during pancreatic regeneration of young rats. Endocrine Research 31 259-270.

Rosenberg L 1995 In vivo cell transformation: neogenesis of beta cells from pancreatic ductal cells. Cell Transplantation 4 371-383.

Rosenberg L \& Vinik AI 1993 In vitro stimulation of hamster pancreatic duct growth by an extract derived from the 'wrapped' pâncreas. Pancreas $8255-260$.

Rosenberg L, Lipsett M, Yoon JW, Prentki M, Wang R, Jun HS, Pittenger GL, Taylor-Fishwick D \& Vinik AI 2004 A pentadecapeptide fragment of islet neogenesis-associated protein increases beta-cell mass and reverses diabetes in C57BL/6J mice. Annals of Surgery 240 875-884.

Silva KE, Barbosa HC, Rafacho A, Bosqueiro JR, Stoppiglia LF, Carneiro EM, Borelli MI, Del Zotto H, Gagliardino JJ \& Boschero AC 2008 INGAP-PP up-regulates the expression of genes and proteins related to $\mathrm{K}(+)$ (ATP) channels and ameliorates $\mathrm{Ca}(2+)$ handling in cultured adult rat islets. Regulatory Peptides 148 39-45.

Tang X, Wang L, Proud CG \& Downes CP 2003 Muscarinic receptor-mediated activation of p70 S6 kinase 1 (S6K1) in 1321N1 astrocytoma cells: permissive role of phosphoinositide 3-kinase. Biochemical Journal 374 137-143.

Thore S, Dyachok O, Gylfe E \& Tengholm A 2005 Feedback activation of phopholipase $\mathrm{C}$ via intracellular mobilization and store-operated influx of $\mathrm{Ca}^{2+}$ in insulin secreting beta cells. Journal of Cell Science 118 4463-4471.

Velloso LA, Carneiro EM, Crepaldi SC, Boschero AC \& Saad MJ 1995 Glucose- and insulin-induced phosphorylation of the insulin receptor and its primary substrates IRS- 1 and IRS- 2 in rat pancreatic islets. FEBS Letters 377 353-357.

Wang RN, Klöppel G \& Bouwens L 1995 Duct- to islet-cell differentiation and islet growth in the pancreas of duct-ligated adult rats. Diabetologia $\mathbf{3 8}$ 1405-1411.

Xu X, D’Hoker J, Stange G, Bonne S, De Leu N, Xiao X, Van De Casteele M, Mellitzer G, Ling Z, Pipeleers D et al. $2008 \beta$-Cells can be generated from endogenous progenitors in injured adult mouse pancreas. Cell 132 197-207.

Yatoh S, Dodge R, Akashi T, Omer A, Sharma A, Weir GC \& Bonner-Weir S 2007 Differentiation of affinity-purified human pancreatic duct cells to beta-cells. Diabetes 56 1802-1809.

Zecchin HG, Priviero FB, Souza CT, Zecchin KG, Prada PO, Carvalheira JB, Velloso LA, Antunes E \& Saad MJ 2007 Defective insulin and acetylcholine induction of endothelial cell-nitric oxide synthase through insulin receptor substrate/Akt signaling pathway in aorta of obese rats. Diabetes 56 1014-1024.

Received in final form 26 August 2008

Accepted 31 August 2008

Made available online as an Accepted Preprint 4 September 2008 